Developments in West European Politics 


\section{Developments in West European Politics}

Edited by

Martin Rhodes

Paul Heywood

Vincent Wright

Macmillan Education 


\section{ISBN 978-0-333-65128-5 ISBN 978-1-349-25341-8 (eBook)}

DOI 10.1007/978-1-349-25341-8

DEVELOPMENTS IN WEST EUROPEAN POLITICS

Copyright (C) 1997 by Martin Rhodes, Paul Heywood, Vincent Wright Individual chapters (in order) (C) Loukas Tsoukalis and Martin Rhodes; Renaud Dehousse; Martin Rhodes; Paul Heywood and Vincent Wright; Yves Mény and Martin Rhodes; Michael Gallagher; Herbert Kitschelt; Colin Crouch and Anand Menon; Martin Rhodes and Bastiaan van Apeldoorn; Phil Cooke, Thomas Christiansen and Gerd Schienstock; Philip Gummett; Ute Collier and Jonathan Golub; Nick Rengger; Raymond Kuhn; Joni Lovenduski; Piero Ignazi 1997 Softcover reprint of the hardcover 1st edition 1997 978-0-333-65127-8

All rights reserved. No part of this book may be used or reproduced in any manner whatsoever without written permission except in the case of brief quotations embodied in critical articles or reviews. For information, address:

St. Martin's Press, Scholarly and Reference Division, 175 Fifth Avenue, New York, N.Y. 10010

First published in the United States of America in 1997

This book is printed on paper suitable for recycling and made from fully managed and sustained forest sources.

ISBN 978-0-312-17339-5

ISBN 978-0-312-17340-1

Library of Congress Cataloging-in-Publication Data

Developments in West European politics/edited by Martin Rhodes, Paul Heywood, Vincent Wright

p. $\mathrm{cm}$.

Includes bibliographical references (p. ) and index.

ISBN 978-0-312-17339-5(cloth). - ISBN 978-0-312-17340-1(paper)

1. European federation. 2. Europe-Economic integration.

3. Europe-Politics and government-1989- I. Rhodes, Martin.

II. Heywood, Paul. III. Wright, Vincent..

JN15.D47 1997

940.55'9-dc21 


\section{Contents}

List of Contributors

Map of Western Europe

$\mathrm{x}$

xii

1 Towards a New Europe? Martin Rhodes, Paul Heywood and Vincent Wright

An era of political change

Globalisation

European integration

The future of democracy and the nation-state

\section{PART ONE: INTEGRATION, GLOBALISATION AND THE NATION STATE}

2 Economic Integration and the Nation-State Loukas

Tsoukalis and Martin Rhodes

State and market in European integration

From common market to regional currency bloc: the origins of monetary integration

Deregulation, internationalisation and the single market programme

Maastricht and the political economy of monetary union

Conclusion

3 European Integration and the Nation-State Renaud

Dehousse

Interdependence and the nation-state

Integration and the fragmentation of state structures

Fragmentation and the depoliticisation of European public policies

Fragmentation and growth of the European Union's powers

Reorganising the state

Conclusion: transnational governance - policies without politics 


\section{PART TWO: GOVERNANCE}

4 The Welfare State: Internal Challenges, External

Constraints Martin Rhodes

Is the welfare state in crisis?

Varieties of welfare: categorising West European social systems

Challenges to welfare - I: domestic developments

Challenges to welfare - II: external constraints

How are welfare states changing?

5 Executives, Bureaucracies and Decision-making Paul

Heywood and Vincent Wright

The structure of European executives: formal roles and real power

Executive-administrative relations $\quad 79$

Decision-making: policy styles and networks $\quad 86$

The challenges facing executives and the changing face of public administration

6 Illicit Governance: Corruption, Scandal and Fraud Yves Mény and Martin Rhodes

Defining corruption, scandal and fraud 96

The causes of corruption

Manifestations of corruption: 'local' cultures and opportunity structures

The European Union: a new transnational 'opportunity structure'?

Conclusion

7 Electoral Systems and Voting Behaviour Michael

Gallagher

The variety of electoral systems in Western Europe

The consequences of electoral systems

Non-voting and political disillusionment

125

Problems of European representation

8 European Party Systems: Continuity and Change Herbert Kitschelt

The basic structure of European party systems 
Three ways of thinking about party system change $\quad 135$

Societal forces promoting party system change 136

The emergence of new parties and changes in the competitive space of European democracies

The resilience of conventional parties

'Europe' as a cleavage line and dimension of competition in party systems?

Conclusion

9 Organised Interests and the State Colin Crouch and Anand Menon

Patterns of organised interests

Changes since the 1980s

Conclusions

\section{PART THREE: PUBLIC POLICY}

10 Capitalism versus Capitalism in Western Europe Martin Rhodes and Bastiaan van Apeldoorn

The diversity of West European capitalisms

System transformation: convergence or parallel evolution?

The European dimension: a transnational model of capitalism?

The emergence of a transnational business 'ideology'

Competing capitalisms and the regulatory framework of embedded neo-liberalism

Conclusion

\section{Regional Economic Policy and a Europe of the}

Regions Phil Cooke, Thomas Christiansen and Gerd

Schienstock

The new economic role of regions

Innovation systems and regional development

Towards regional productivity coalitions

The enabling role of EC Structural Funds

Competition for foreign direct investment and European funds

The relationship between the 'global' and the 'local' 
12 Foreign, Defence and Security Policy Philip Gummett 207

The early postwar context $\quad 207$

The nuclear states $\quad 211$

NATO nuclear policy $\quad 214$

The end of the Cold War 215

Towards a new security framework? 219

What role for the European Union? 223

13 Environmental Policy and Politics Ute Collier and Jonathan Golub

National environmental policy and politics 226

The significance of Green parties 233

Multi-level environmental policy 234

The subsidiarity debate $\quad 239$

New challenges and opportunities $\quad 240$

Conclusions $\quad 242$

PART FOUR: POLITICS, IDEOLOGY AND FUTURE CHALLENGES

14 Beyond Liberal Politics? European Modernity and the Nation-State Nick Rengger

The emergence of a postmodern politics? 247

Assessments 255

Responses $\quad 259$

15 The Media and Politics Raymond Kuhn 263

Media diversity in Western Europe 264

Common media policy issues in Western Europe 266

Technological change $\quad 267$

Concentration of ownership $\quad 270$

Transnationalisation $\quad 271$

Media regulation 271

The 'Europeanisation' of media policy 274

The 'mediatisation' of West European politics 276

Conclusion 279

16 The Integration of Feminism into West European

Politics Joni Lovenduski 281

Women, feminism and gender 283

Behaviour: political representation and participation 283 
Policy: women's issues $\quad 288$

Equal opportunities $\quad 289$

Male violence - I: sexual assault 293

Male violence - II: sexual harassment 294

Institutions: state feminism 296

Conclusions 298

17 New Challenges: Post-Materialism and the Extreme

Right Piero Ignazi $\quad 300$

Defining the new party families $\quad 300$

The electoral performance and development of extreme right and Green parties $\quad 304$

Hypotheses on the origin and development of new parties $\quad 307$

The new parties and spatial analysis $\quad 315$

$\begin{array}{ll}\text { Conclusion } & 318\end{array}$

Guide to Further Reading $\quad 320$

Bibliography $\quad 325$

Index 351 


\section{List of Contributors}

Thomas Christiansen is a Research Fellow in the Department of Government, University of Essex, England.

Ute Collier is a Jean Monnet Fellow in the Robert Schuman Centre, European University Institute, San Domenico di Fiesole, Florence, Italy.

Phil Cooke is Professor of Regional Development and Director of the Centre for Advanced Studies in Social Sciences, University of Wales College of Cardiff, Wales.

Colin Crouch is Professor of Sociology in the Department of Social and Political Science, European University Institute, San Domenico di Fiesole, Florence, Italy.

Renaud Dehousse is Professor of Law in the Department of Law, European University Institute, San Domenico di Fiesole, Florence, Italy.

Michael Gallagher is a Lecturer in Politics, Department of Political Science, Trinity College, University of Dublin, Ireland.

Jonathan Golub is a Research Fellow in the Robert Schuman Centre, European University Institute, San Domenico di Fiesole, Florence, Italy.

Philip Gummett is Professor of Politics and Science and Technology, Department of Government, University of Manchester, England.

Paul Heywood is Professor of Politics, Department of Politics, University of Nottingham, England.

Piero Ignazi is Professor of Political Science, Dipartimento di Politica, Istituzione, Storia, Università degli Studi di Bologna, Italy. 
Herbert Kitschelt is Professor of Political Science, Department of Political Science, Duke University, Durham, North Carolina, USA.

Raymond Kuhn is Senior Lecturer in the Department of Political Studies, Queen Mary and Westfield College, University of London, England.

Joni Lovenduski is Professor of Politics, Department of Politics, University of Southampton, England.

Anand Menon is Lecturer in the Politics of European Integration, University of Oxford, England.

Yves Mény is Director of the Robert Schuman Centre, European University Institute, San Domenico di Fiesole, Florence, Italy.

Nick Rengger is Reader in Political Theory and International Relations in the School of History and International Relations, University of St Andrews, Scotland.

Martin Rhodes is Senior Research Fellow in the Robert Schuman Centre, European University Institute, San Domenico di Fiesole, Florence, Italy.

Gerd Schienstock is Director of the Work Research Centre, University of Tampere, Finland.

Loukas Tsoukalis is Professor of European Integration at the University of Athens and Director of European Studies at the College of Europe in Bruges.

Bastiaan van Apeldoorn is a PhD student at the European University Institute, San Domenico di Fiesole, Florence, Italy.

Vincent Wright is an Official in Politics, Nuffield College, Oxford, England, and a Fellow of the British Academy. 


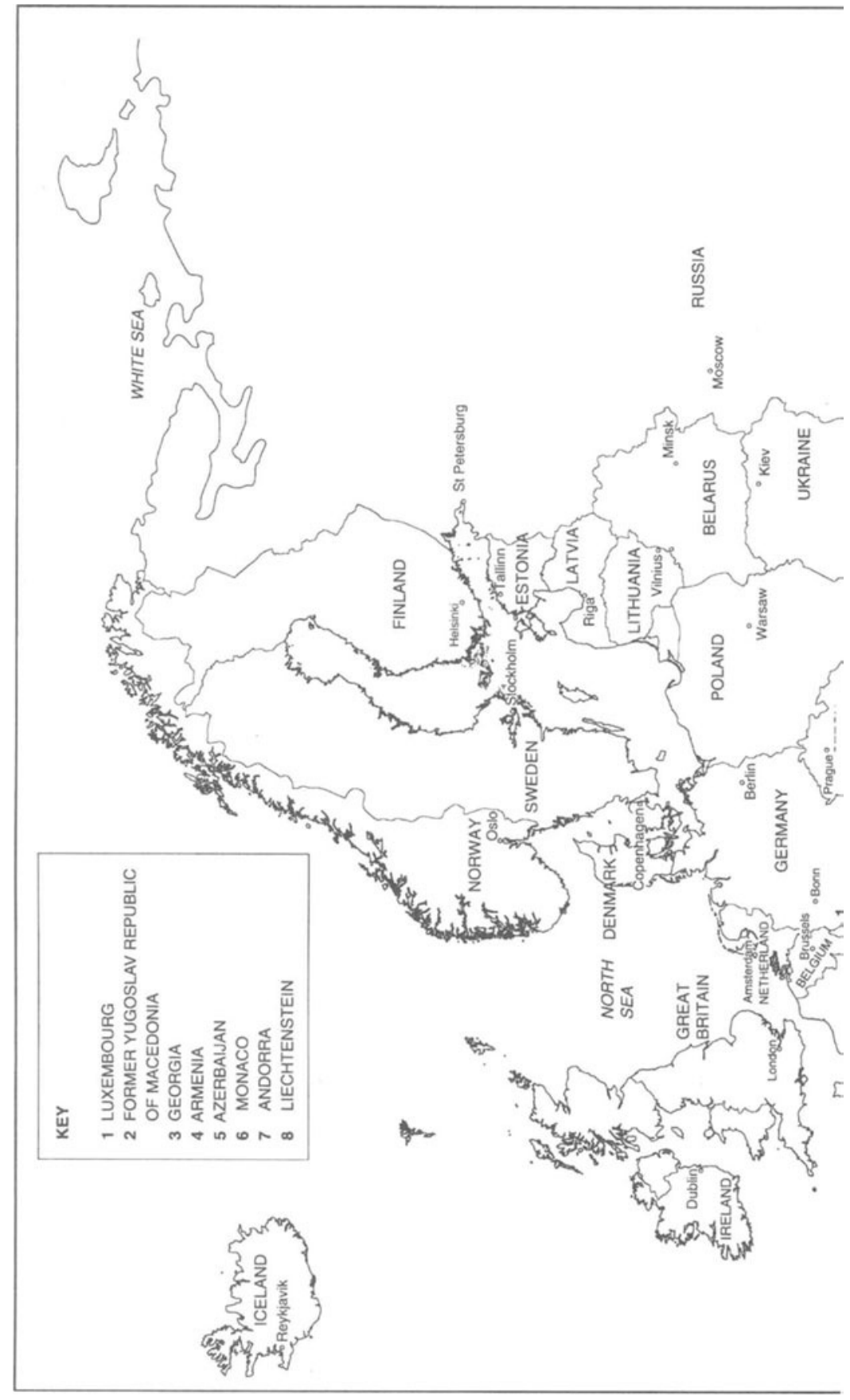




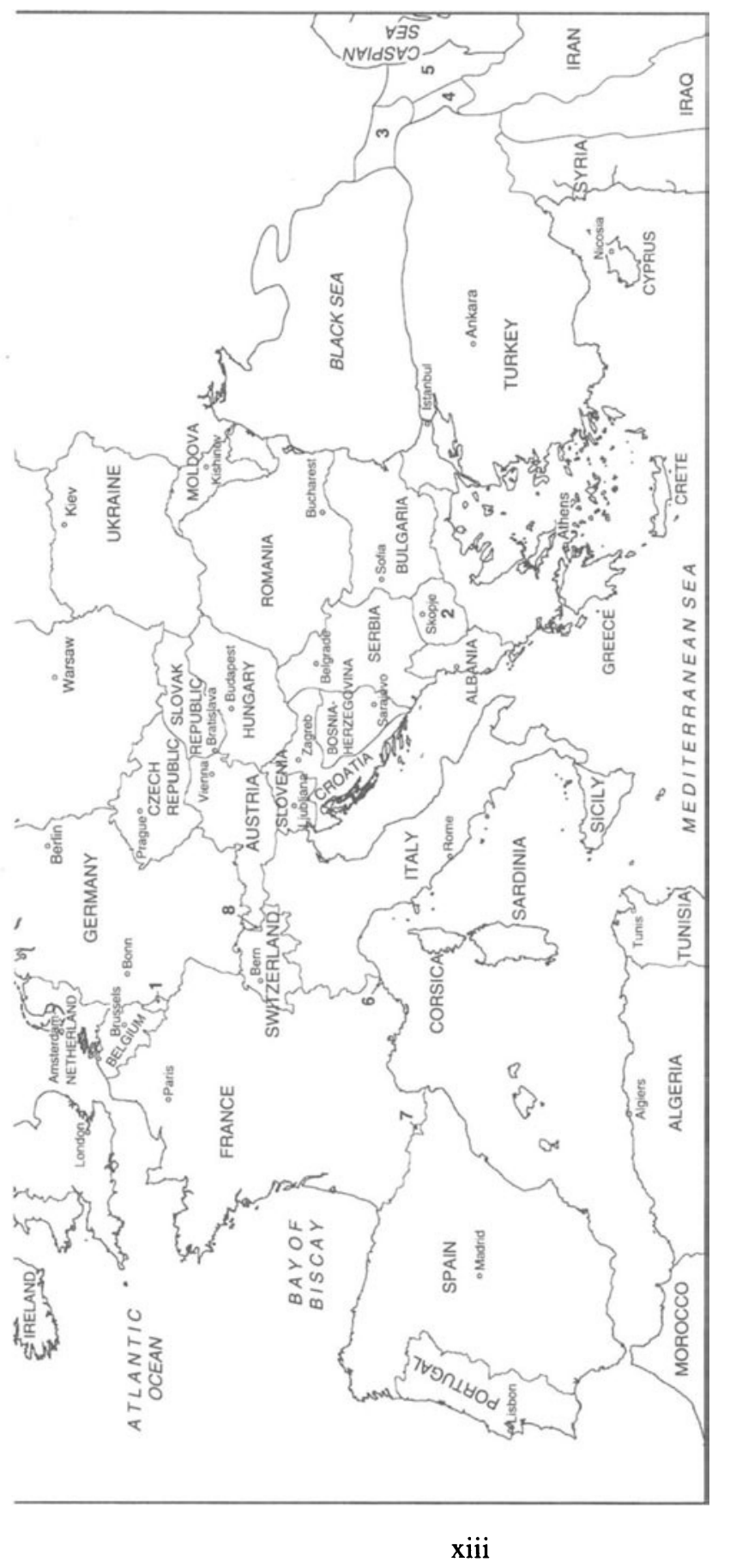

